\title{
PENINGKATAN ANGKA KONSUMSI IKAN MELALUI DIVERSIFIKASI PRODUK OLAHAN IKAN DI KECAMATAN BANYUATES KABUPATEN SAMPANG
}

\section{INCREASING FISH CONSUMPTION FIGURES THROUGH DIVERSIFICATION OF PROCESSED FISH PRODUCTS IN BANYUATES DISTRICT, SAMPANG REGENCY}

\author{
Kustiawan Tri Pursetyo \\ Fakultas Perikanan dan Kelautan \\ Pulung Siswantara \\ Fakultas Perikanan dan Kelautan
}

\author{
Annur Ahadi Abdillah \\ Fakultas Perikanan dan Kelautan \\ Heru Pramono \\ Fakultas Perikanan dan Kelautan
}

Eka Saputra

Fakultas Perikanan dan Kelautan

\begin{abstract}
ABSTRAK
Program Pengabdian Kepada Masyarakat ini bertujuan untuk meningkatkan pengetahuan para kelompok nelayan ikan melalui penyuluhan dan pelatihan, maka Tim Pengabdian Kepada Masyarakat Universitas Airlangga melakukan transfer alih teknologi bagi masyarakat pengolahan produk perikanan di Kecamatan Banyuates, Kabupaten Sampang. Sebagai khalayak sasaran yang akan diikutsertakan dalam program Pengabdian Kepada Masyarakat ini adalah ketua, pengurus serta kelompok nelayan ikan, aparat desa setempat dan petugas Dinas Peternakan setempat yang diharapkan nantinya dapat bertindak sebagai motivator. Diharapkan nantinya dapat diandalkan sebagai sumber untuk kesinambungan program alih teknologi. Metode yang digunakan dalam pelaksanaan kegiatan pengabdian kepada masyarakat ini adalah dengan cara; (1) Tahap Pembinaan dan pelatihan; (2) Tahap monitoring dan evaluasi, Untuk mengevaluasi tingkat pengetahuan dan pemahaman terhadap materi yang diberikan maka diberikan pretest dan post test. Kegiatan program Pengabdian Kepada Masyarakat ini akan dilaksanakan mulai bulan Juni sampai dengan Oktober 2017. Untuk meningkatkan angka konsumsi ikan, terlebih dahulu Tim pelaksana kegiatan melakukan sosialisasi kepada siswa SD agar lebih mengenal tentang berbagai macam ikan beserta manfaatnya. Selepas kegiatan sosialisasi dilakukan kegiatan penyuluhan dan pelatihan pembuatan aneka produk olahan berbahan dasar ikan, dengan menggunakan metode tutorial, kemudian dilanjutkan dengan diskusi.
\end{abstract}

Kata kunci: produk olahan, ikan, Banyuates, Sampang

\begin{abstract}
The Community Service Program aims to increase the knowledge of fish fishermen groups through counseling and training, then the Airlangga University Community Service Team transfers technology transfer to fishery product processing communities in Banyuates District, Sampang Regency. As target audiences that will be included in this Community Service program are the chairman, management and fish fishermen group, local village officials and local Animal Husbandry Service officers who are expected to later act as motivators. It is hoped that later it can be relied upon as a source for the sustainability of the technology transfer program. The method used in the implementation of community service activities is by way of; (1) Development and training phase; (2) Monitoring and evaluation phase, To evaluate the level of knowledge and understanding of the material provided, it is given pretest and post test. This Community Service program will be carried out
\end{abstract}




\begin{abstract}
from June to October 2017. To improve fish consumption, first the implementation team conducts socialization activities to elementary students to get to know more about various kinds of fish and their benefits. After the socialization activities, counseling activities and training were made on various fish-based processed products, using the tutorial method, then continued with discussion.
\end{abstract}

Keywords: processed products, fish, Banyuates, Sampang

\section{PENDAHULUAN}

Dalam sektor perikanan Indonesia memiliki potensi yang sangat besar. Potensi sumber daya perikanan baik perikanan tangkap, budi daya laut, perairan umum dan lainnya diperkirakan mencapai US\$ 82 miliar per tahun. Potensi perikanan tangkap mencapai US\$ 15,1 miliar per tahun, potensi budi daya laut sebesar US\$ 46,7 miliar per tahun, potensi perairan umum sebesar US\$ 1,1 miliar per tahun, potensi budi daya tambak sebesar US\$ 10 miliar per tahun, potensi budi daya air tawar sebesar US\$ 5,2 miliar per tahun, dan potensi bioteknologi kelautan sebesar US\$ 4 miliar per tahun (KKP, 2011).

Melihat data resapan tenaga kerja yang dibutuhkan dalam sector perikanan yang cukup besar inilah, maka dapat dikatakan bahwa nilai produksi ikan di Indonesia cukup besar dan mempunyai peluang ekspor yang tinggi di luar negeri. Menurut data Kementerian Kelautan dan Perikanan (KKP) nilai ekspor perikanan Indonesia dari tahun ke tahun cenderung meningkat. Ditahun 2009 nilai ekspor perikanan Indonesia mencapai 2,5 Miliar USD dan di tahun 2010 meningkat menjadi 2,8 Miliar USD. Selain itu angka konsumsi ikan per kapita Indonesia juga semakin meningkat. Ditahun 2009 konsumsi ikan masyarakat Indonesia mencapai 29, $08 \mathrm{~kg}$ per kapita/thn dan meningkat di tahun 2010 menjadi 30, $48 \mathrm{~kg}$ per kapita/thn. Saat ini konsumsi ikan masyarakat Indonesia pada tahun 2015 sebesar 41,11 kg per kapita/tahun. Hal ini menunjukkan bahwasanya masyarakat Indonesia sadar akan pentingnya kebutuhan protein khususnya hewani sehingga diperlukan suatu upaya dalam meningkatkan konsumsi ikan setiap tahunnya.

Kecamatan Banyuates, Kabupaten Sampang merupakan salah satu kecamatan yang memiliki potensi perikanan cukup tinggi, dikarenakan lokasi kecamatan ini langsung berbatasan dengan laut Jawa. Selain itu, kecamatan Banyuates juga terdapat waduk Nipah yang dapat digunakan sebagai sarana budi daya ikan. Melihat potensi besar di bidang perikanan, maka diperlukan upaya pengembangan pengelolaan ikan yang tepat sehingga akan menyadarkan masyarakat sekitar untuk lebih sering mengonsumsi ikan sebagai lauk utama.

Untuk mencapai kondisi tersebut perlu dilakukan peningkatan keterampilan dan pengetahuan tentang cara pembuatan aneka produk perikanan serta cara pengemasannya yang praktis dan menarik sehingga mempermudah pemasaran dengan harga jual yang lebih baik bila dibandingkan dengan pemasaran ikan segar.

Untuk itu tim pengabdian kepada masyarakat UNAIR ingin melakukan transfer alih teknologi guna meningkatkan pendapatan masyarakat nelayan ikan melalui pembinaan pembuatan aneka produk berbahan dasar ikan, dimana hal ini menjadi salah satu pelaksanaan Tri Dharma Perguruan Tinggi yaitu Pengabdian Kepada Masyarakat.

\section{PERMASALAHAN MITRA}

Ikan merupakan sumber pangan hewani yang mengandung sumber protein, vitamin, mineral dan asam amino esensial yang mempunyai peran penting untuk mencukupi nutrisi tubuh manusia. Ikan merupakan produk segar yang mudah rusak dan menjadi suatu permasalahan yang umum bagi konsumen, produsen serta penjual makanan. Selain umur yang relatif singkat ikan juga dapat menimbulkan keracunan karena proteinnya yang tinggi sehingga mikroorganisme patogen dapat tumbuh dan mengeluarkan toksin yang mengakibatkan keracunan (Hakim, 2010).

Beberapa nelayan tradisional dalam proses penanganan ikan hasil tangkap masih menggunakan es batu yang bertujuan agar ikan kondisinya masih segar ketika sampai di darat. Akan tetapi, untuk mempertahankan kondisi ikan terus segar dengan menggunakan es batu dengan kondisi perjalanan waktu dari laut ke darat yang cukup panjang, terkadang berimbas kepada kebutuhan jumlah es batu yang harus dibawa. Banyaknya kebutuhan es batu dan cepatnya proses melelehnya es batu ketika perjalanan berdampak pada jumlah uang yang harus dikeluarkan oleh nelayan. Selain itu, penggunaan es batu hanya membantu proses pengawetan ikan berlangsung hanya beberapa hari saja atau bahkan cuma bertahan 24 jam.

Persoalan yang lebih mendasar dalam kondisi sekarang adalah meningkatkan pendapatan dan ekonomi masyarakat nelayan di kecamatan Banyuates Kabupaten Sampang, dengan jalan melakukan upaya diversifikasi usaha pengolahan ikan guna meningkatkan nilai pendapatan masyarakat sekitar, selain itu sebagai sarana untuk meningkatkan angka konsumsi ikan di kecamatan tersebut.

Dengan melakukan Pengabdian Kepada Masyarakat melalui pengolahan produk perikanan dan cara pengemasan (packing) yang praktis dan menarik di kecamatan 
Banyuates Kabupaten Sampang dapat dirumuskan beberapa permasalahan:

1. Sejauh mana peningkatan pengetahuan nelayan tentang pembuatan Aneka Produk Perikanan dan cara pengemasan (packing) yang praktis?

2. Sejauh mana peningkatan pendapatan nelayan setelah melakukan penjualan Aneka Produk Perikanan hasil home industrinya?

\section{METODE PELAKSANAAN}

Untuk meningkatkan pengetahuan kelompok ibu-ibu nelayan dalam hal pembuatan olahan ikan dan cara pengemasan (packing) yang praktis guna meningkatkan nilai jual ikan yang lebih tinggi, maka Tim Pengabdian Kepada Masyarakat Universitas Airlangga akan melakukan transfer alih teknologi bagi masyarakat nelayan ikan di wilayah kecamatan Banyuates Kabupaten Sampang.

Teknologi yang akan diberikan berupa pembuatan nugget ikan, ikan asap cair dan olahan produk ikan yang lain serta cara pengemasan (packing) yang praktis, upaya teknologi ini agar tidak ada produk perikanan segar yang rusak dan meningkatkan harga ikan agar tercapai peningkatan pendapatan nelayan.

Tahap awal pada pelaksanaan program pengabdian kepada masyarakat ini yaitu melakukan survey ke daerah sasaran yaitu para nelayan di kawasan kecamatan Banyuates Kabupaten Sampang untuk menentukan sasaran kegiatan Pengabdian Kepada Masyarakat.

Tahap selanjutnya dilakukan koordinasi antara pengurus kelompok nelayan ikan dengan pihak yang terkait yaitu dengan Unit Pelaksana Teknis maupun dengan Tim Pengabdian Kepada Masyarakat Universitas Airlangga untuk menentukan jadwal kegiatan.

Kelompok ikan di Banyuates, Sampang ini merupakan kelompok nelayan yang mempunyai usaha di bidang penangkapan ikan. Untuk meningkatkan pengetahuan para nelayan maupun keluarga nelayan maka tim pelaksana program Pengabdian Kepada Masyarakat berusaha memberi motivasi maupun alih teknologi cara pembuatan aneka produk olahan berbahan dasar ikan yang mempunyai nilai jual lebih tinggi. Adapun materi-materi yang diberikan pada kegiatan Pengabdian Kepada Masyarakat ini adalah sebagai berikut:

1. Manfaat Ikan bagi kesehatan.

2. Pembuatan Nugget, Ikan asap dan Abon ikan berbahan dasar ikan.

3. Berbagai bentuk dan cara packing yang aman, higienis dan menarik.

4. Analisis ekonomi dan cara pemasaran produk olahan ikan.

Metode yang digunakan dalam pelaksanaan kegiatan pengabdian kepada masyarakat ini dilakukan dalam tiga tahap kegiatan meliputi:

1. Tahap Pembinaan:

Pada tahap pembinaan ini dilaksanakan dengan mengundang kelompok nelayan termasuk penyuluh lapangan dinas kabupaten Sampang dengan menggunakan metode tutorial dan visualisasi dengan menggunakan LCD .

2. Tahap Pelatihan

Dalam upaya untuk meningkatkan keterampilan dan pengetahuan Nelayan akan dilakukan demo serta pelatihan cara pembuatan aneka produk olahan berbahan dasar ikan agar nantinya dapat menerapkan teknologi ini secara baik dan benar.

3. Tahap Evaluasi

Para anggota dan pengurus Kelompok Nelayan Ikan yang mengikuti pelatihan diuji pre dan post test.

Partisipasi mitra dalam program Iptek bagi Masyarakat adalah keikutsertaan ketua kelompok Ikan beserta anggota , Tim Perikanan (Penyuluh) dalam Kelompok Nelayan tersebut dan petugas Dinas Perikanan setempat yang diharapkan nantinya bertindak sebagai motivator, dimana secara keseluruhan jumlah peserta pelatihan 10-20 orang.

Tabel 1. Luas Tanah Setiap Dusun

\begin{tabular}{lcccc}
\hline Dusun & $\begin{array}{c}\text { Lahan Sawah } \\
(\mathbf{H a})\end{array}$ & $\begin{array}{c}\text { Lahan Tegal } \\
(\mathbf{H a})\end{array}$ & $\begin{array}{c}\text { Lahan Pekarangan } \\
(\text { Ha) }\end{array}$ & $\begin{array}{c}\text { Lain-lain } \\
\text { (Ha) }\end{array}$ \\
\hline Gendungan & 12,7 & 66,33 & 8,14 & 6,25 \\
Batioh & 17,50 & 49,80 & 9,27 & 6,45 \\
Duwe' Assen & - & 28,75 & 8,76 & 5,72 \\
Wa'Duwak & - & 30,25 & 9,83 & 6,39 \\
Kapasan & - & 21,51 & 7,81 & 5,38 \\
Lon Selleng & 15,40 & 35,60 & 7,95 & 5,65 \\
\hline Jumlah & 45,37 & 232,24 & 51,77 & 35,84 \\
\hline
\end{tabular}




\section{HASIL DAN PEMBAHASAN}

Desa Batioh sebagai desa wilayah pantai dengan batas wilayah sebelah utara laut, timur Desa Tlagah, sebelah selatan Desa Montor, sebelah barat Desa Masaran memiliki luas tanah 3,70 $\mathrm{km}^{2}$ atau 2,62\% dari luas wilayah Kecamatan Banyuates yang dimanfaatkan masyarakat untuk lahan persawahan seluas 45,37 Ha dan lahan kering seluas 324,423 Ha. Desa Batioh memiliki 6 Dusun yakni Dusun Gendungan, Dusun Batioh, Dusun Duwe'assen, Dusun Wa'duwak, Dusun Kapasan dan Dusun Lon Selleng. Adapun luas tanah untuk setiap dusun terdapat di Tabel 1

\section{Demografi}

Adapun demografi penduduk Batioh tahun 2014 dengan kepadatan penduduk 1031,35 tersusun pada tabel di bawah ini;

\begin{tabular}{ll}
\hline \multicolumn{1}{c}{ Jumlah Penduduk } & $\mathbf{3 . 8 2 6}$ jiwa \\
\hline Laki-laki & 1.808 jiwa \\
Perempuan & 2.018 jiwa \\
\multicolumn{1}{c}{ Jumlah KK } & \\
\hline
\end{tabular}

\section{Ekonomi}

Bidang perekonomian masyarakat Desa Batioh berdasarkan perusahaan rumah tangga, yaitu:

\begin{tabular}{llc}
\hline Rumah Tangga & Tanaman Pangan & $\mathbf{5 7 7}$ \\
\cline { 2 - 3 } \multicolumn{1}{c}{ Pertanian } & \multicolumn{1}{c}{ Perikanan } & $\mathbf{9 1}$ \\
\hline Rumah Tangga Non & Perdagangan & 186 \\
Pertanian & Angkutan & 60 \\
& Industri & 12 \\
& Penggalian & 3 \\
& Pertukangan & 10 \\
& Jasa & 14 \\
\hline
\end{tabular}

Berdasarkan data jumlah kegiatan perikanan yang ada di desa Batioh adalah berjumlah 91 kegiatan yang didominasi oleh kegiatan perikanan tangkap. Kegiatan penangkapan ikan dilakukan dengan cara tradisional dan belum dilakukan pengolahan ikan dengan baik dan benar. Untuk lahan tambak untuk kegiatan perikanan masih belum ada, sehingga memiliki potensi yang besar untuk dikembangkan di sektor perikanan.

\section{IMPLEMENTASI PROGRAM KEGIATAN}

Kegiatan pertama pengabdian kepada masyarakat yang dilakukan oleh pelaksana pengabdian masyarakat bekerjasama dengan mahasiswa KKN-BBM 56. Tahap pelaksana awal adalah dilakukan sosialisasi kepada siswa-siswi SDN 1 dan 2 Batioh untuk mengenalkan beberapa jenis ikan yang memiliki nilai ekonomi tinggi.
Setelah itu dilakukan kegiatan menggambar dan mewarnai ikan. Peserta yang hadir dalam kegiatan ini adalah sebanyak 60 siswa yang dibagi menjadi 2 sekolah, Kegiatan ini dilaksanakan pada tanggal 19 Agustus 2017.

Setelah kegiatan sosialisasi tentang ikan, dilaksanakan kegiatan pelatihan pengolahan produk perikanan yang dilaksanakan pada tanggal 16 September 2017 di Balai Desa Batioh, Kecamatan Banyuates, Kabupaten Sampang. Peserta yang hadir adalah ibu-ibu nelayan sebanyak 10 orang, penyuluh sebanyak 3 orang dan 2 mahasiswa. Kegiatan awal penyuluhan dilaksanakan dengan cara memberikan informasi bahaya akan formalin. Kegiatan ini bertujuan untuk memberikan informasi tentang bahaya pengawet kimia. Dalam pemberian penyuluhan ini, masyarakat cukup antusias dalam berdiskusi terkait dengan penggunaan bahan alternatif alami pengganti formalin.

Materi yang diberikan pertama kali adalah informasi tentang bahaya penggunaan bahan pengawet kimia, dalam hal ini penggunaan formalin pada ikan. Pada materi ini, masyarakat diberikan informasi seputar bahan berbahaya pangan yang di larang oleh pemerintah. Informasi ini diberikan dalam metode penyuluhan dan pemberian booklet kepada peserta.

Setelah pemaparan bahaya penggunaan bahan pengawet non pangan dilakukan juga pemberian informasi tentang bahan alami yang dapat dipakai sebagai bahan pengawet ikan semisal biji kluwek, kunyit dan asap cair. Sehingga dengan penambahan informasi tersebut, diharapkan masyarakat mampu menghindari penggunaan bahan pengawet yang dilarang oleh pemerintah. Dalam penyampaian materi tersebut, terjadi sesi tanya jawab antara peserta dengan pemberi materi yaitu Kustiawan Tri Pursetyo, S.Pi, M.Vet terkait dengan penggunaan formalin. Usut punya usut, ternyata masyarakat masih tidak begitu mengetahui bahaya penggunaan formalin baik dalam jumlah sedikit atau banyak.

Selepas kegiatan penyuluhan bahaya akan formalin, peserta dibekali penyuluhan penggunaan asap cair sebagai alternative dalam pengawetan dan pengolahan ikan. Dalam kegiatan ini pemateri adalah Bapak Heru Pramono, S.Pi, M.Biotech, proses pengawetan dan pengolahan ikan menggunakan asap cair dapat memberikan umur simpan ikan bertahan sampai 2-5 hari.

Dengan pemberian materi tentang pengolahan ikan dengan menggunakan asap cair masyarakat sangat mengapresiasi kehadiran tim pengmas, karena dengan adanya sosialisasi ini, ibu-ibu nelayan lebih mengetahui secara luas dan jelas tentang cara pengolahan serta pengawetan ikan yang baik dan benar. Saran yang kami terima dari masyarakat cukup banyak, salah satunya adalah mereka sangat menginginkan kembali adanya pelatihan terkait pemasaran yang baik dan benar. 
Dampak langsung yang dirasakan oleh peserta pelatihan adalah bertambahnya wawasan mengenai cara pengolahan ikan yang baik dan benar, sehingga tidak merusak sumber protein yang terkandung didalam tubuh ikan. Harapan dari kegiatan ini adalah masyarakat mampu mengolah ikan sebagai sumber protein utama di keluarga mereka masing-masing.

Dampak yang dirasakan oleh mahasiswa yang terlibat dalam program pengabdian masyarakat ini adalah mereka dapat mengembangkan kemampuan soft skill secara terapan kepada masyarakat. Selain itu, mereka juga mendapatkan wawasan seputar kendala dalam dunia perikanan baik mulai terkait dengan kebutuhan modal, sarana dan prasarana maupun dalam hal pemasaran hasil produk perikanan.

\section{RENCANA KEBERLANJUTAN PROGRAM}

Program yang potensial yang diharapkan untuk menjadi program lanjutan adalah dengan melakukan pelatihan dan penyuluhan yang difokuskan dalam peningkatan pengetahuan tentang cara pemasaran produk hasil perikanan. Hal ini sangat potensial dikarenakan Desa Batioh merupakan desa yang memiliki pantai dengan Hutan Kera yang ada di pantai utara Madura. Kemungkinan besar yang bisa dilakukan untuk melaksanakan program tersebut adalah dengan metode pelatihan pemasaran dan promosi melalui media sosial dan e-commerce yang dapat diimplementasikan pada kegiatan selanjutnya.

Dukungan dari masyarakat terhadap kegiatan ini sangat besar, hal ini ditunjukkan dengan antusiasme masyarakat dalam mendukung kegiatan ini dan permintaan program yang berkelanjutan untuk tahun depan. Selain itu, mereka sangat berharap pada tim pengmas untuk membantu dalam pengelolaan finansial terkait dengan pembentukan serta pembinaan koperasi simpan pinjam.

\section{KESIMPULAN DAN SARAN}

Dari kegiatan pengabdian kepada masyarakat yang telah dilaksanakan dapat disimpulkan bahwa a) secara umum pengetahuan tentang jenis-jenis ikan konsumsi pada siswa SDN 1 dan 2 Batioh semakin meningkat, b) masyarakat lebih mengetahui tentang pendeteksian dini bahan pengawet formalin secara ilmiah, c) masyarakat dapat melakukan pengolahan ikan dengan metode asap cair sehingga dapat menambah daya simpan umur ikan.

Dalam pengembangan program pengabdian kepada masyarakat selanjutnya sebaiknya materi lebih disinkronisasi dengan kesulitan pada kelompok nelayan dalam hal pemasaran ikan dan olahan hasil produk perikanan.

\section{DAFTAR PUSTAKA}

Benita, R.T. 2011. Perkembangan Sejarah Perikanan di Indonesia. http://nitazeggers.blogspot.com/2012/04/ perkembangan-sejarah-perikanan-di.html. Diakses 13 Agustus 2017

Hakim, L. 2010. Sintesis Biofilm Ubi Jalar Yang Mengandung Antimikroba Dari Kitosan Sebagai Upaya Memperpanjang Umur Simpan Dan Bioindikator Kerusakan Ikan Tongkol. Skripsi Institut Pertanian Bogor. Bogor

Kementerian Kelautan dan Perikanan (KKP). 2011. Sumberdaya dan Potensi Perikanan Indonesia. http:// www.kkp.go.id. Diakses 13 Agustus 2017 